\title{
Folate nutrition in the kid
}

\author{
By J. E. FORD, G. S. KNAGGS, D. N. SALTER \\ AND K. J. SCOTT \\ National Institute for Research in Dairying, Shinfield, Reading $R G 2{ }_{9} A T$
}

(Received 17 September 1971 - Accepted 10 November 1971)

\begin{abstract}
I. A study was made on the folate content of goat's milk in relation to stage of lactation, and on the interrelationship between blood and milk folate concentrations in the dam and in the kid.

2. In seven goats the folate concentration in the colostrum at parturition ranged from ${ }_{3} 6$ to $300 \mathrm{ng} / \mathrm{ml}$, and averaged $205 \mathrm{ng} / \mathrm{ml}$. The concentration fell sharply during the early days of lactation and by day 14 it averaged only $9.5 \mathrm{ng} / \mathrm{ml}$. This pattern of rapid decline in milk folate concentration with advancing lactation was little affected by daily provision of folic acid parenterally in relatively large amounts.

3. The colostrum and milk contained a minor whey protein that combined strongly with folate, and presumably acts as a trapping mechanism to accumulate the vitamin from the plasma into the milk. The milk folate concentration is determined by the rate of milk secretion in relation to the availability of free folate in the blood plasma.

4. At parturition the plasma folate concentration in the kids was very low - about $\mathrm{I} \mathrm{ng} / \mathrm{ml}-$ but by day 2 it had increased to about $28 \mathrm{ng} / \mathrm{ml}$. This folate was protein-bound and accompanied by an excess of free binder protein. It appeared that the folate-protein complex from the colostrum was transmitted intact into the kids' blood circulation.

5. The possible importance of the folate-binding protein in the regulation of folate metabolism is discussed.
\end{abstract}

Goat's milk is a comparatively poor source of folate. It contains about $6 \mathrm{ng} / \mathrm{ml}$ as against $50 \mathrm{ng} / \mathrm{ml}$ in human milk and cow's milk, and its prolonged consumption as the sole diet by suckling infants may cause 'goat's milk anaemia', which is now recognized as being a megaloblastic anaemia symptomatic of folate deficiency (Becroft \& Holland, I 966). In man the metabolic turnover of folate is rapid and any severe restriction of dietary intake is quickly followed by a fall in serum folate and a slower progressive fall in red cell folate (Herbert, 1962). These observations prompted speculation on the folate nutrition of the newborn kid, and the present paper reports on the folate content of goat's milk in relation to stage of lactation, and on some interrelationships between blood and milk folate concentrations in the dam and in the kid.

\section{EXPERIMENTAL}

Pedigree British Saanen goats of the Institute herd were used. They were maintained on clover hay and concentrates and given daily access to pasture. They were brought indoors each evening and housed on concrete in individual pens. On the expected day of parturition and for about a week thereafter the goats were kept indoors. The kids remained in the pens for 3 weeks, during which time they were suckled by their dams and also had access to hay and concentrates.

Some of the goats were milked pre-partum, as deemed necessary by the goatherd, 
to relieve painful distension of the udder and as a prophylactic measure against mastitis.

For the measurement of blood and milk folate concentrations during the first 4 weeks of lactation, three primiparous and three multiparous goats were selected. Samples of blood and milk were taken at parturition and at 2, 7, r $4,2 \mathrm{I}$ and $28 \mathrm{~d}$ thereafter. Further samples were taken from some of the animals at intervals before parturition. None of these animals was milked pre-partum. Blood samples were taken from the newly born kids before suckling, and again at 2, 7, I4, 21 and $28 \mathrm{~d}$.

In a parallel experiment, blood and milk samples were taken, as described below, from four multiparous goats that had been milked pre-partum.

\section{Sampling procedure}

Blood samples (10-20 ml) were taken by venepuncture from the jugular vein, into $28.4 \mathrm{ml}$ McCartney bottles to which had been added I drop of heparin (supplying approximately 20 i.u./ml blood) and $\mathrm{o} \cdot \mathrm{I} \mathrm{ml}$ of tris-ascorbate buffer $(\mathrm{pH} 7)$, containing $4 \mathrm{mg}$ ascorbic acid. Two subsamples were transferred to Wintrobe haematocrit tubes for determination of the packed cell volume (PCV). A further $2 \mathrm{ml}$ portion was diluted to $10 \mathrm{ml}$ by addition of $\mathrm{I} \%(\mathrm{w} / \mathrm{v})$ aqueous solution of ascorbic acid, as recommended by Hoffbrand, Newcombe \& Mollin ( 1966 ) for the assay of whole blood folate. The remainder was centrifuged at $10000 \mathrm{~g}$ for Io min and the plasma layer transferred by pipette into a $7 \mathrm{ml}$ 'bijou' bottle.

The milk samples - about $20 \mathrm{ml}$ - were also taken into $28 \cdot 4 \mathrm{ml} \mathrm{McCartney} \mathrm{bottles}$ containing $O^{\circ} \mathrm{I} \mathrm{ml}$ of the tris-ascorbate buffer.

All the samples were stored at $-30^{\circ}$ until required for folate assay.

\section{Administration of iron-dextran to the kids}

Preliminary experiments showed that the PCV values for the kid's blood fell from about $40 \%$ at parturition to a minimum around $20 \%$ at about $\mathrm{r} 4 \mathrm{~d}$ after parturition, and then began to recover. The decline was prevented by intramuscular injection of $200 \mathrm{mg}$ iron as iron-dextran complex (Imposil 200; Fisons Ltd), and all the kids used in the experiments now reported were given this treatment as a prophylactic measure.

\section{Influence of parenteral folic acid on milk and blood plasma folate concentrations}

From a primiparous goat in the 3 rd month of lactation and yielding about $4.6 \mathrm{~kg}$ milk daily, samples of milk and blood were taken over an $8 \mathrm{~d}$ period, in accordance with the following schedule:

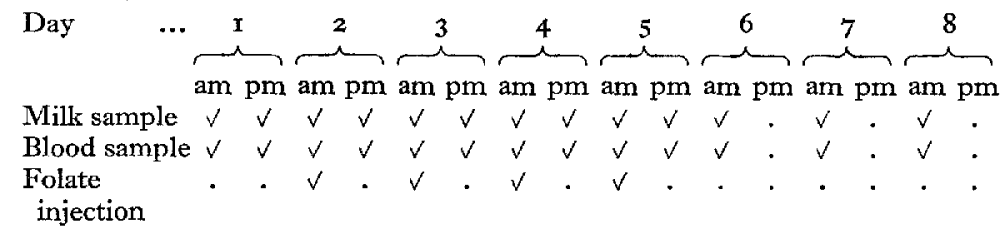

Folic acid ( $2 \mathrm{ml}$ of solution containing $\mathrm{I} \mathrm{mg} / \mathrm{ml}$ in $0.9 \%$ saline) was given by intramuscular injection on the morning of days $2-5$, immediately after the samples of 
blood and milk had been taken. The blood samples were centrifuged to provide plasma for assay.

\section{Whole body folate in the kid}

The aim in this experiment was to compare whole body folate in twin male kids, one of which was to be killed at parturition and the other at 3 weeks of age. In the event no suitable twin pairs became available and instead four unrelated male kids were selected. Two were killed at parturition before suckling and two after suckling for 3 weeks. The animals were skinned and the livers and guts removed. Each liver was weighed and homogenized with three times its weight of phosphate-ascorbate buffer at $\mathrm{pH} 7.8$ (see below). The gut contents were washed out with phosphate-ascorbate buffer and homogenized. The empty gut was combined with the carcass and the whole weighed and then minced. A portion of the mince was homogenized with phosphate-ascorbate buffer. Samples of the various homogenates were stored at $-30^{\circ}$ until required for folate assay. Test extracts were prepared essentially as described for the milk samples.

The skins were discarded and their folate content was not taken into account.

\section{Folate assays}

Folic acid activity was assayed microbiologically with Lactobacillus casei by the procedure of Herbert (196i).

Preparation of chicken pancreas enzyme. To $2.5 \mathrm{~g}$ of desiccated chicken pancreas (Difco Laboratories Inc., Detroit, USA) were added $25 \mathrm{ml}$ of ice-cold buffer solu-

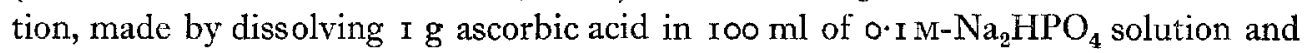
adding $4 \mathrm{M}-\mathrm{NaOH}$ solution to $\mathrm{pH} 7 \cdot 8$. The mixture was homogenized gently in a testtube with a close-fitting pestle of polytetrafluoroethylene, and centrifuged for $15 \mathrm{~min}$ at $15000 \mathrm{~g}$. The supernatant fluid was filtered through Whatman no. 42 paper, and its content of free folate removed by fractional filtration in a column of Sephadex gel $\mathrm{G} \mathrm{25}$; the folate conjugase was eluted from the column with the protein front, at near the void volume. The protein-containing fractions werc combined and diluted to $50 \mathrm{ml}$ with the buffer, and further diluted fivefold before use.

Preparation of the test extracts. Extracts of milk and colostrum were made as follows. To $2 \mathrm{ml}$ samples in $\mathrm{I} 5 \times 150 \mathrm{~mm}$ test-tubes was added $\mathrm{I} \mathrm{ml}$ of the buffer solution. The tubes were heated in flowing steam for $2 \mathrm{~min}$ and cooled in cold water, and to each was added $\mathrm{I} \mathrm{ml}$ of the extract of chicken pancreas. The tubes were incubated for $2 \mathrm{~h}$ in a water-bath at $45^{\circ}$. The contents were then acidified to $\mathrm{pH}_{4} .8$ by addition of $0 . \mathrm{Im}-\mathrm{HCl}$, diluted with water to $5^{\circ} \mathrm{ml}$ and filtered through Whatman no. 42 paper. The filtrates were adjusted to $\mathrm{pH} 6.8$ and further diluted as needed for test.

Extracts of whole blood were prepared as described for human blood by Hoffbrand et al. (1966), using a smaller final dilution to compensate for the lower folate content in goat's blood. The plasma samples were extracted by a modification of the method of Waters \& Mollin (196I). To $2 \mathrm{ml}$ samples in $20 \times 150 \mathrm{~mm}$ test-tubes werc added $8 \mathrm{ml} \mathrm{O} \cdot \mathrm{I} \mathrm{M}$-phosphate buffer of $\mathrm{pH} 6 . \mathrm{I}$ containing $200 \mathrm{mg}$ ascorbic acid/100 $\mathrm{ml}$. The tubes were autoclaved for $2.5 \mathrm{~min}$ at $115^{\circ}$ and cooled in a water-bath. The contents 


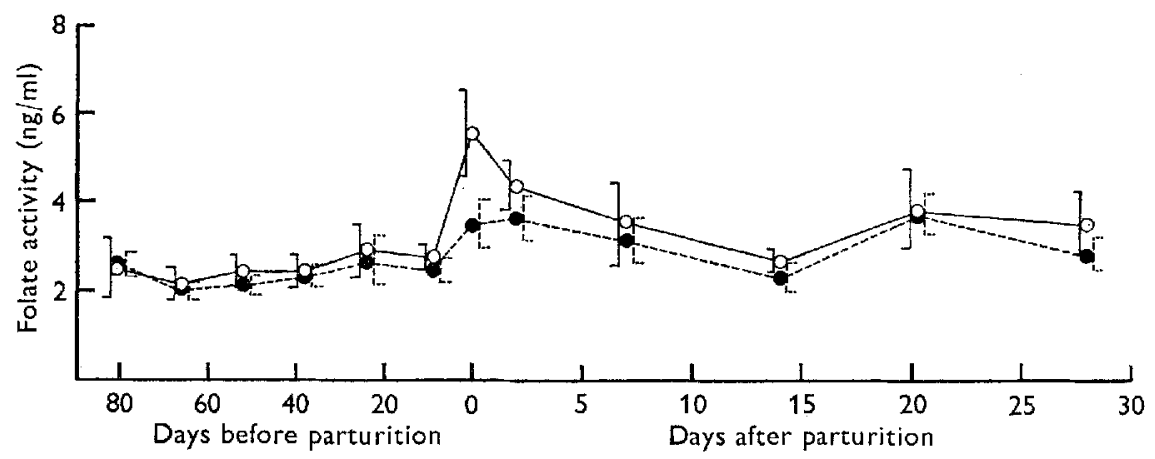

Fig. I. Folate concentration in blood $(\mathrm{O}-\mathrm{O})$ and blood plasma $(----\infty)$ of nine goats. Bars indicate standard errors of means. Haematocrit values range from 3 I to $34 \%$.

were adjusted to $\mathrm{pH}_{4} \cdot 6$, diluted to $30 \mathrm{ml}$ with water, and filtered through Whatman no. 42 paper. The filtrate was then adjusted to $\mathrm{pH} 6 \cdot 8$.

The concentration of folate in the red blood cells was calculated by subtracting the folate content of the plasma in the samples from that of the whole blood, and then correcting for the haematocrit value.

\section{Measurement of folic acid-binding capacity of milk and blood plasma}

Both in the human and in the cow, the accumulation of folate into the milk seems to be connected with the presence in the milk of a minor whey protein to which folate binds strongly (Ford, Salter \& Scott, r 969; Ghitis, Mandelbaum-Shavit \& Grossowicz, 1969). It seemed possible therefore that the low-folate content of mature goat's milk might reflect a comparatively low level of folate binding activity.

Samples of blood and milk were taken from a goat at parturition and again on the $7^{\text {th }}$ and the 3 oth day of lactation. The blood samples were centrifuged to provide plasma for test.

To eight I $\mathrm{ml}$ portions of each sample of plasma and milk were added $2 \mathrm{ml}$ buffer solution of $\mathrm{pH}_{7.2}$ containing $0.15 \mathrm{M}-\mathrm{NaCl}, 0.02 \mathrm{M}$-sodium phosphate and $0.00 \mathrm{IM}$ ascorbic acid, and graded amounts of folic acid dissolved in I $\mathrm{ml}$ buffer. A $2 \mathrm{ml}$ sample of each mixture was then transferred to a sac of $8 \mathrm{~mm}$ cellulose dialysis tubing and dialysed for $48 \mathrm{~h}$ at $2^{\circ}$ against eight successive $100 \mathrm{ml}$ portions of buffer. The residual folate activity in the sacs was then assayed.

\section{RESULTS AND DISCUSSION}

\section{Folate content of goat's blood}

Fig. I shows the folate concentrations in the whole blood and plasma of six goats. They showed no large change over the period of the experiment, but there was a small increase at parturition. Preliminary experiments (Ford \& Scott, r969) had shown an average blood folate concentration of $7 \mathrm{ng} / \mathrm{ml}$ at parturition, which declined during the following $28 \mathrm{~d}$ to $2.3 \mathrm{ng} / \mathrm{ml}$. It is not certain that this increase in the blood folate concentration at parturition was directly connected with the large secretion of folate 


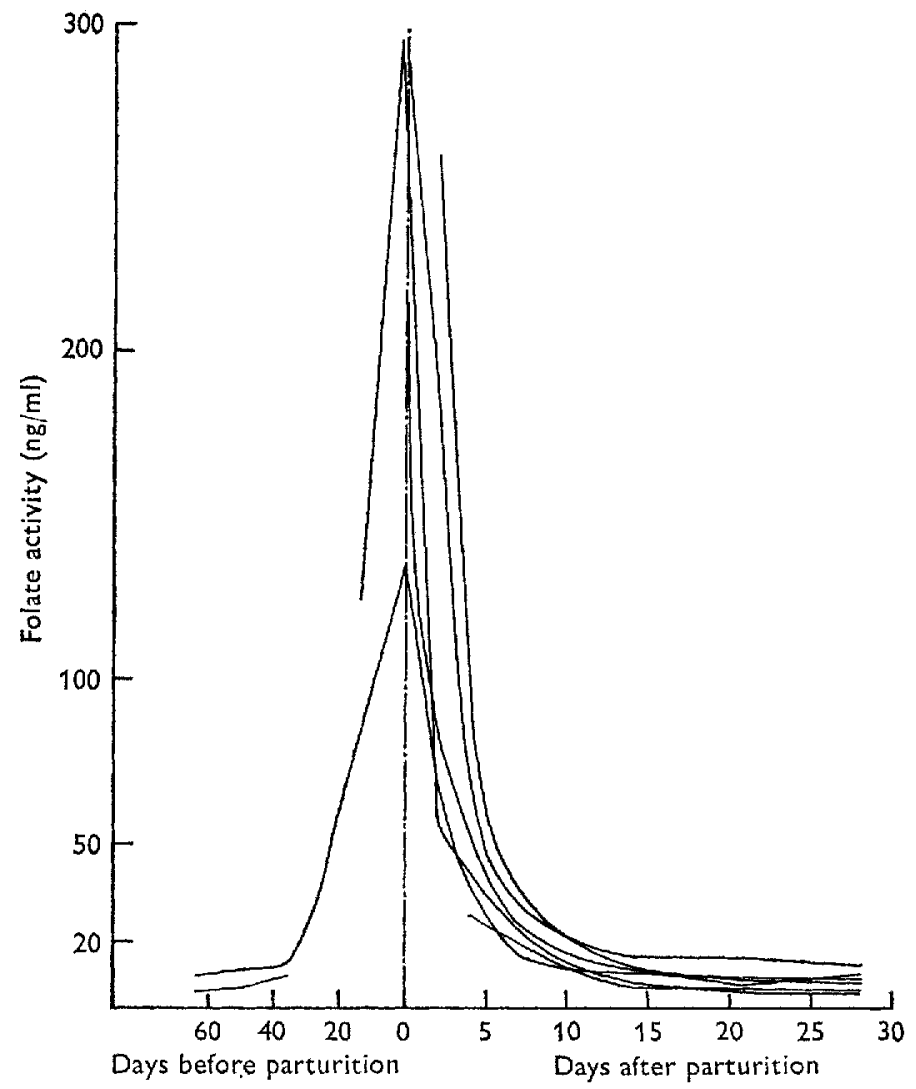

Fig. 2. Folate concentrations in samples of milk from six goats,

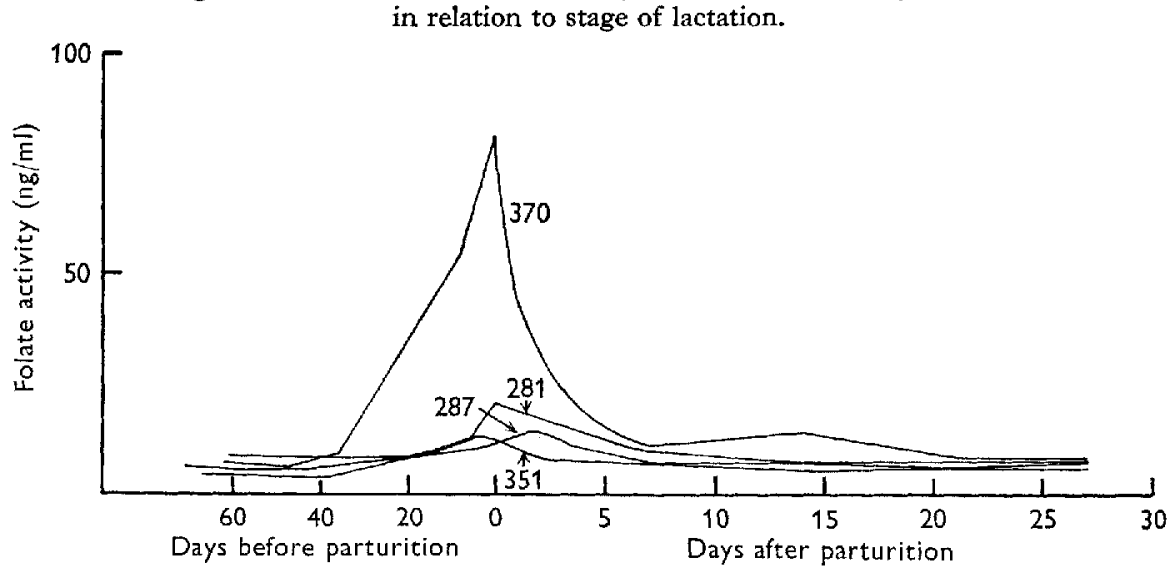

Fig. 3. Folate concentrations in samples of milk from four multiparous goats that had been milked pre-partum. The animals were milked as follows: goat $35 \mathrm{I}$, every $3 \mathrm{~d}$ until $2 \mathrm{~d}$ before parturition and then twice daily; goat $28 \mathrm{I}$, every $2 \mathrm{~d}$ until $4 \mathrm{~d}$ before parturition; goat 287 , daily until $5 \mathrm{~d}$ before parturition; goat 370 , every $3 \mathrm{~d}$ until $2 \mathrm{~d}$ before parturition. 


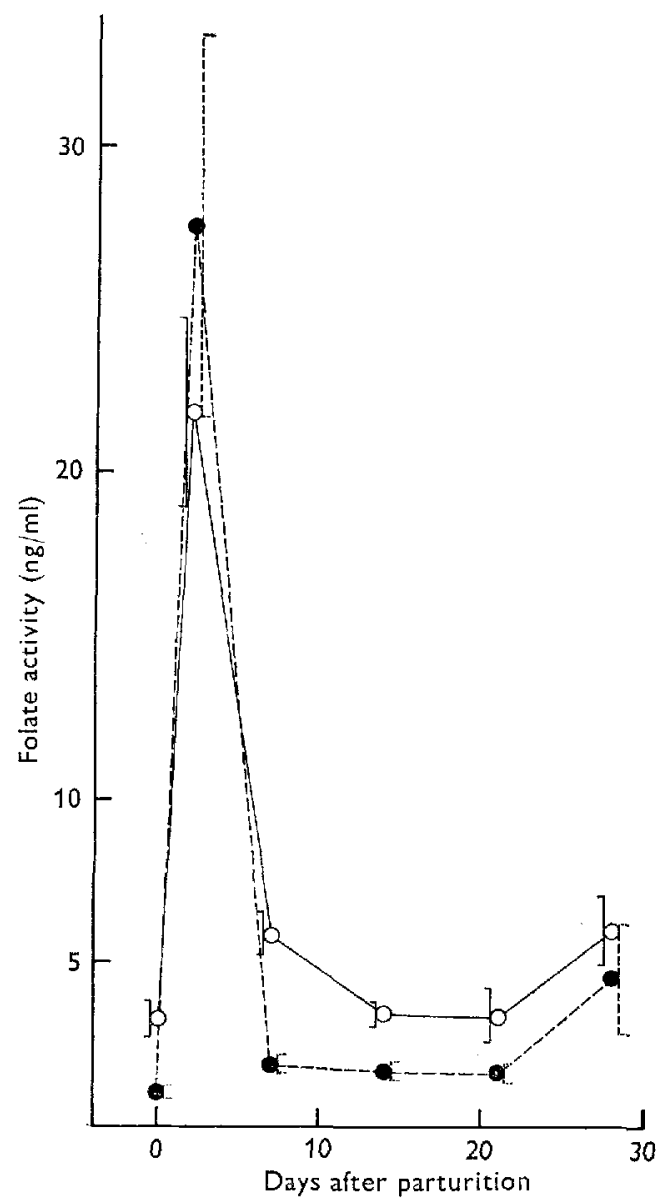

Fig. 4. Folate concentration in blood $(\mathrm{O}-\mathrm{O})$ and blood plasma $(-1-0)$ of nine kids. Bars indicate standard errors of means. Haematocrit values ranged from $3 \mathrm{r}$ to $38 \%$

in the colostrum: it might have had less to do with the physiology of milk folate secretion than with the change in feeding and management (see p. 57I). It is possible, however, that the increase reflected a mobilization of folate from the liver and other tissues.

\section{Folate content of milk in relation to stage of lactation}

Fig. 2 shows the folate concentration in samples of colostrum and milk taken from six goats during the first 4 weeks of lactation, and from three of the animals at intervals before parturition.

At parturition the folate concentration in the colostrum was comparatively high and ranged up to about $300 \mathrm{ng} / \mathrm{ml}$. It fell sharply during the early days of lactation and by day I 4 averaged only $9.5 \mathrm{ng} / \mathrm{ml}$. This pattern is qualitatively broadly similar to that reported for the dairy cow (Karlin, 1967) but in the goat the contrast between the folate concentrations in colostrum and mature milk was more extreme. In the human the pattern is normally different; the folate concentration is low in colostrum 


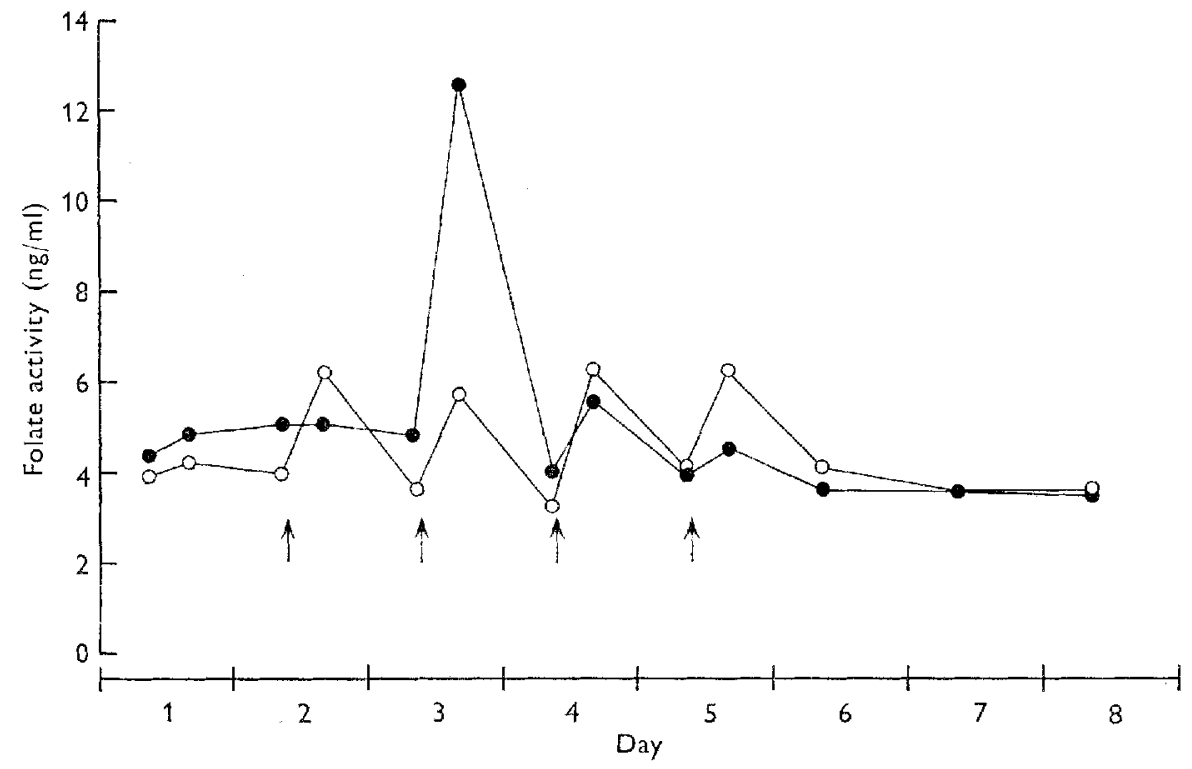

Fig. 5. Influence of parenteral folic acid on the folate activity in milk (-C) and blood plasma $(\mathrm{O}-\mathrm{O})$ of a goat. Folic acid $(2 \mathrm{mg})$ was injected intramuscularly on days $2-5$, immediately after the morning samples of blood and milk had been taken, as indicated by the arrows.

and immature milk and increases to a sustained high level around $5 \circ \mathrm{ng} / \mathrm{ml}$ in mature milk (Karlin, 1967 ).

The results shown in Fig. 2 are for goats that had not been milked pre-partum. Fig. 3 shows, for comparison, the results obtained with four multiparous goats that had been milked-out up to near the date of parturition. Two of the animals, $37^{\circ}$ and $28 \mathrm{r}$, were milked daily until 4 weeks before parturition, and then two or three times weekly. Goat $35^{\mathrm{I}}$ was milked daily until I week before parturition, and twice daily for the $2 \mathrm{~d}$ before parturition. For three of these four goats the folate concentrations in the colostrum were little higher than those in the mature milk. For the remaining goat, no. $37^{\circ}$, the peak in the folate content at parturition was more pronounced, but still low by comparison with the 'normal' values shown in Fig. 2. It seems reasonable to conclude that the different pattern of folate secretion in these four animals was caused by the pre-partum milking, and that the high folate concentration in normal colostrum is not determined by the event of parturition.

\section{Folate content of the kid's blood}

The folate in human milk is efficiently absorbed from the gut (Ghitis \& Tripathy, 1970) and the results set out in Fig. 4 indicate that the same is true for goat's milk. The figure shows the pattern of changes in the folate concentration in the blood of six kids of the goats whose mill folate values are illustrated in Fig. 2. At parturition the plasma folate concentration was very low - about I $\mathrm{ng} / \mathrm{ml}$ - but by day 2 it had increased to about $28 \mathrm{ng} / \mathrm{ml}$. This increase was only transitory and by day 7 the plasma folate had 
Table $\mathrm{I}$. Influence of parenteral folic acid on the folate activity of blood and milk

(20 $\mathrm{mg}$ folic acid were injected intramuscularly at parturition, and again at 7,14 and $2 \mathrm{I}$. Samples of milk and blood were taken before each injection)

\begin{tabular}{|c|c|c|c|c|c|}
\hline & \multicolumn{5}{|c|}{ Folate activity (ng/ml) } \\
\hline & Day $\mathbf{I}$ & Day 2 & Day 7 & Day 14 & Day 2I \\
\hline \multicolumn{6}{|c|}{ Goat J-257; primiparous, not milked pre-partum } \\
\hline Milk & 136 & 78 & Io & $5 \cdot 5$ & $2 \cdot 3$ \\
\hline Blood & $4 \cdot 4$ & $6 \cdot 0$ & $4 \cdot 7$ & $4 \cdot 7$ & $4: 9$ \\
\hline Blood plasma & $5 \cdot 2$ & $6 \cdot 8$ & $3 \cdot 6$ & $3 \cdot 7$ & 377 \\
\hline \multicolumn{6}{|c|}{ Goat K-294; multiparous, milked pre-partum } \\
\hline Milk & $4 \cdot 0$ & $4 \cdot 5$ & $5^{\cdot I}$ & $5 \cdot 2$ & $4 \cdot 0$ \\
\hline Blood & $4^{\circ} 0$ & $5 \cdot 5$ & $5 \cdot 5$ & 4.5 & $5 \cdot 3$ \\
\hline Blood plasma & $2 \cdot 4$ & 3.4 & $4 \cdot 5$ & $3 \cdot 2$ & 3.8 \\
\hline
\end{tabular}

fallen again, to about $2 \mathrm{ng} / \mathrm{ml}$. At day 28 the value again increased, to about $5 \mathrm{ng} / \mathrm{ml}$. This same general pattern was also found in several kids that were not included in the present experiment, and the small rise in blood folate at day 28 was clearly significant. It presumably reflected the transition to a solid diet and the establishment of the rumen function.

\section{Influence of parenteral folic acid on milk and blood plasma folate activity}

Metz, Zalusky \& Herbert (I968) observed that in lactating women with folate deficiency severe enough to provoke megaloblastic anaemia, orally administered folic acid was taken up by the milk in preference even to the haemopoietic system. It seemed unlikely, therefore, that the low folate content of mature goat's milk could be explained in terms of depletion of the maternal stores of available folate, and adverse equilibrium between uptake of folate from the gut and physiological demand. However, to test the possibility, $2 \mathrm{mg}$ folic acid were administered by intramuscular injection on each of 4 successive days, and the effects on blood and milk folate concentrations determined. The results of the experiment are shown in Fig. 5. The injected folic acid had only a fleeting influence on the plasma folate concentration. After $6 \mathrm{~h}$ the plasma concentrations had increased by about $2 \mathrm{ng}$ folate $/ \mathrm{ml}$, equivalent in the whole body plasma to less than $0.5 \%$ of the injected dose. After a further $\mathrm{I} 7 \mathrm{~h}$ the concentration had fallen again to the initial value. This same sequence was observed after each of the four injections. The red cell folate was unchanged during the experiment.

The effects of repeated doses of folic acid on the milk folate concentration were less uniform. The first injection caused no increase in milk folate at the afternoon milking. This recalls the finding by Metz et al. ( $\mathrm{I} 968$ ) that it takes up to $48 \mathrm{~h}$ for parenterally injected folic acid to appear in human breast-milk, suggesting that the vitamin is first incorporated in the mammary columnar epithelial cells and then becomes part of the apocrine secretion. The second injection was followed by a sharp increase, from $4^{\cdot 6}$ 


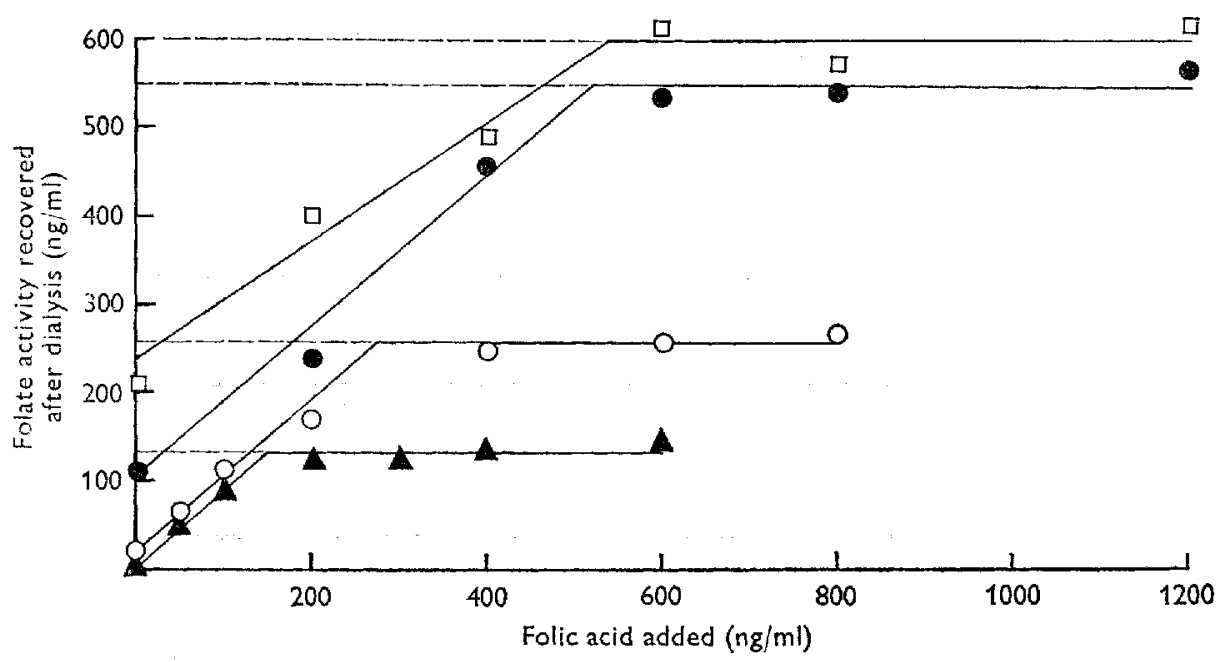

Fig. 6. Binding of folic acid added to goat's colostrum and milk. Goat 380 . $\square$, colostrum, day $\mathrm{x} ; \bullet$, milk, day $2 ; 0$, milk, day $7 ; \boldsymbol{A}$, milk, day 30 . The intercepts of the dotted lines on the vertical axis show the amounts of folic acid activity retained per $\mathrm{ml}$ of sample after prolonged dialysis.

to $12 \cdot 6 \mathrm{ng} / \mathrm{ml}$, representing in the afternoon milk yield about $\mathrm{x} \%$ of the injected dose. The subsequent injections caused smaller increases in the milk folate concentrations; there was no indication of a sustained increase. The effects of the injections were transitory, as they were on the plasma folate concentration.

In a further experiment, $20 \mathrm{mg}$ folic acid were injected intramuscularly into two goats, at parturition and again at $7, I_{4}$ and $2 \mathrm{I}$ d. Samples of milk and blood were taken before each injection and assayed for folate activity. The results are shown in Table $\mathbf{x}$.

In goat $\mathrm{J}-257$ the milk folate concentration showed the typical precipitous fall during the early days of lactation, despite the massive injections of folic acid, levelling off at a concentration broadly similar to that in the blood plasma.

Goat K-294 had been regularly milked-out up to the day of parturition, and so the folate concentration in its colostrum and milk was uniformly low. As with goat J-257, the injected folic acid had little influence on the milk folate concentration, which again was broadly similar to that in the blood plasma. From these results it is clear that the normal pattern of decline in milk folate concentration with advancing lactation was little affected by the provision of folic acid parenterally in relatively large amounts. Johns, Sperti \& Burgen (I96r) demonstrated that the body tissues extract folic acid from the blood plasma with great avidity, and this high capacity of the tissues to accumulate and bind folic acid probably explains the relative ineffectiveness of parenteral folic acid in increasing the milk folate level.

It may be that larger doses of folic acid would have caused a sustained increase in the plasma and milk folate concentrations. The test doses were chosen on the assumption that the daily folate requirement of the goat is about $200 \mu \mathrm{g}$, a 'guesstimate' which assumes that the requirement per kg body-weight is similar to that in a lactating woman. On this basis the injections of $2 \mathrm{mg}$ were perhaps already 


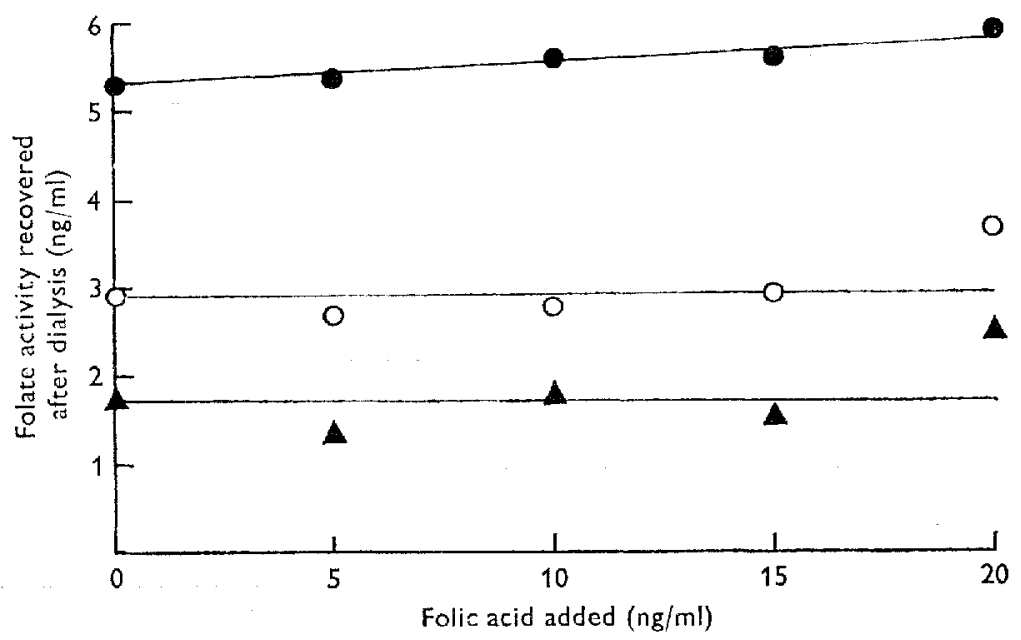

Fig. 7. Absence of folic acid-binding activity in samples of goat's blood plasma, taken at intervals after parturition. Goat 380 , $\bullet$, day $x ; 0$, day $7 ; \boldsymbol{\Lambda}$, day 30 .

on the high side, and the $20 \mathrm{mg}$ injections could be regarded as being grossly unphysiological. It is planned to repeat the experiment, but with the folic acid given by continuous intravenous irrigation at about $50 \mu \mathrm{g} / \mathrm{h}$.

\section{Folic acid binding capacity of milk and blood plasma}

A further possible explanation for the rapid fall in the folate content of the milk during early lactation is that there is a corresponding fall in the content of folatebinding protein in the milk, and therefore in the capacity of the milk to accumulate folate from the blood plasma against a concentration gradient (cf. Ford et al. 1969). Fig. 6 shows the capacity of colostrum taken at parturition, and of milk taken at intervals up to the 3 oth day of lactation, to bind added folic acid.

The colostrum had the capacity to bind about $600 \mathrm{ng}$ folate activity per $\mathrm{ml}$, and folic acid added in excess of this threshold concentration was not retained against dialysis. The natural folate in the colostrum was also bound, and wholly retained in the dialysed sample. Thus, the colostrum contained a high concentration of bound folate, and also a considerable excess of folate-binding protein. With advancing lactation the folate content of the milk declines, as did also the capacity of the milk to bind added folic acid. By day 30 the natural folate concentration had fallen from 2 ro to $5 \mathrm{ng} / \mathrm{ml}$, and the folate-binding capacity from 600 to $130 \mathrm{ng} / \mathrm{ml}$. However, the mature milk still contained more folate binder than did cow's milk, and so the relatively very low folate content was not wholly explained simply by the lower folate-binding capacity.

The presumption that the physiological role of the folate binder in milk is to trap folate from the blood plasma implies that some or all of the plasma folate occurs in the free form, and is not already firmly bound in protein. Fig. 7 shows that the plasma, unlike the colostrum and milk, had no capacity to bind added folic acid. However, the plasma folate was largely protein-bound, like that in the milk. The total folate activity 
Table 2. Folate activity in the blood plasma and mature milk of cows and goats

$\begin{array}{lcccc}\text { Range } & \text { Mean } & \overbrace{\text { Range }}^{\text {Milk folate }(\mathrm{ng} / \mathrm{ml})} \\ \text { Goats (9) } & \begin{array}{c}0.9-6.8 \\ 16-39\end{array} & 3 \cdot \mathrm{I} & 5 \cdot 5^{-1} 3 \cdot 0 & 9 \cdot 0 \\ \text { Cows* (9) } & 26 & 30-80 & 55\end{array}$

Figures in parentheses are the numbers of animals.

* Ford and Scott (unpublished).

Table 3. Free and bound folate, and folate-binding capacity, in samples of blood plasma of kids taken at parturition before suckling, and at 2 and $2 \mathrm{I} d$

$\begin{array}{cccc}\text { Time of sampling } & \text { Total } & \text { Bound* } & \begin{array}{c}\text { Added folate } \\ \text { bound (ng/ml) }\end{array} \\ \text { At parturition } & \mathbf{I} \cdot 9 & 5 \cdot 3 & 0 \\ \text { 2 d } & 58 & 58 & 24 \\ \text { 2 I d } & 2 \cdot 4 & 2 \cdot \mathbf{I} & 0\end{array}$

* Measured after prolonged dialysis of the plasma sample (see p. 574).

in the day I sample was $5.5 \mathrm{ng} / \mathrm{ml}$, and this was not significantly reduced after $2 \mathrm{~d}$ dialysis. With the day 7 sample, dialysis reduced the folate activity from $7^{\cdot}$ I to $3^{\circ} \circ \mathrm{ng} /$ $\mathrm{ml}$, and with the day 30 sample from 3.4 to $\times .8 \mathrm{ng} / \mathrm{ml}$. The content of folate binder in the plasma, like that in the milk, declined with advancing lactation, but there was no evident relationship between the concentration of free folate in the plasma and the folate content of the milk, or between the proportions of free and bound plasma folate and stage of lactation.

These findings provide no support for the concept that folate binder acts as a trapping mechanism that accumulates free folate from the plasma into the milk. However, it must also be taken into account that the colostrum is secreted comparatively slowly, and it may be supposed that there would be ample time for its folate binder to accumulate a high concentration of folate, even though 11 of colostrum would clear the free folate from several hundreds of litres of blood plasma.

The rapid fall in the milk folate concentration during the few days after parturition may be largely attributable to dilution of the initial folate content. After parturition the milk is secreted at a faster rate and its folate content might be limited by the availability of free folate in the plasma, or by the rate at which plasma folate taken up into the milk is replenished from the body stores. In this connexion, it is of interest to compare the folate content of the blood plasma and mature milk of cows (Ford and Scott, unpublished) with the corresponding values for the goats (Table 2). The differences in the milk concentrations were matched by corresponding differences in the plasma folate concentrations. Furthermore, the comparatively high concentration in the cow's blood plasma was very largely present as free folate. For three of the cows the plasma folate concentrations were $22, \mathrm{I} 7$ and $\mathrm{I} 6 \mathrm{ng} / \mathrm{ml}$; after dialysis of the plasma the corresponding values were 3,4 and $5 \mathrm{ng} / \mathrm{ml}$. 'Thus, from these findings it seems 
Table 4. Whole body and liver folate in four male kids, two of which had been killed at parturition before suckling, and two after suckling for 3 weeks

\begin{tabular}{|c|c|c|c|c|c|c|c|}
\hline \multirow{3}{*}{$\begin{array}{c}\text { Kid } \\
\text { no. }\end{array}$} & \multirow{3}{*}{$\begin{array}{l}\text { Time of } \\
\text { killing }\end{array}$} & \multirow{3}{*}{$\begin{array}{l}\text { Live body- } \\
\text { weight (kg) }\end{array}$} & \multicolumn{5}{|c|}{ Folate $(\mu \mathrm{g})$ in } \\
\hline & & & \multicolumn{2}{|c|}{ Body* } & \multicolumn{2}{|c|}{ Liver } & \multirow{2}{*}{$\begin{array}{c}\text { Gut } \\
\text { contents, } \\
\text { total }\end{array}$} \\
\hline & & & Per g & Total & Per $\mathrm{g}$ & Total & \\
\hline 397 & At birth & $4 \cdot 23$ & 0.11 & 357 & 2.05 & 231 & - \\
\hline $43^{\circ}$ & At birth & $4 \cdot 55$ & O.II & 400 & I. 85 & 228 & - \\
\hline 261 & At 3 weeks & 10.90 & 0.08 & 604 & I'08 & 412 & I 33 \\
\hline 297 & At 3 weeks & $8 \cdot 90$ & 0.07 & 454 & 0.96 & 237 & 259 \\
\hline
\end{tabular}

that the milk folate concentration is primarily determined by the rate of secretion in relation to the availability of free folate in the blood plasma, and that the milk's content of folate binder does not limit the milk folate concentration. It also seems probable that the binder protein in colostrum and milk is of local origin within the mammary gland. Alternatively, it might conceivably be concentrated from the blood plasma, like the immune globulins, but if this were so, then the high degree of unsaturation with folate would remain to be explained.

\section{Intestinal absorption of bound folate in the newborn kid}

During a period lasting only a few hours from birth, the gut of the newborn ruminant transmits intact protein freely and non-selectively, and it is believed that the young animal receives into its circulation all the proteins that occur in the colostrum. The folate-protein is clearly no exception, since the high concentration of folate in blood plasma of 2-d-old kids was protein-bound and wholly retained in the plasma during prolonged dialysis. Table 3 shows the content of bound folate, and the folate-binding capacity, in samples of blood plasma taken from a kid at parturition before suckling, and at 2 and $21 \mathrm{~d}$. The high concentration of bound folate at day 2 was accompanied, as in the milk, by a high concentration of free folate binder. At day 21 the plasma, unlike the milk (see Fig. 6), contained no free binder, and it seems that the period during which the intact binder is taken up from the gut is limited, though whether by 'cut off' in absorption or by destruction of the binder by the growing population of rumen micro-organisms is not evident from this experiment.

\section{Whole body folate in the kid}

Table 4 shows the whole body and liver folate in four male kids, two of which had been killed at parturition before suckling and two after suckling for 3 weeks. At birth the total liver folate averaged $230 \mu \mathrm{g}$, and comprised about $60 \%$ of the total content of the body. The liver content at 3 weeks averaged $325 \mu \mathrm{g}$, but the concentration had fallen from $\mathrm{r} \cdot 95$ to $\mathrm{r} \cdot 02 \mu \mathrm{g} / \mathrm{g}$. For comparison, the folate concentration in the livers of six castrated adult male goats ranged from 5.5 to $9.8 \mu \mathrm{g} / \mathrm{g}$, and averaged $6.9 \mu \mathrm{g} / \mathrm{g}$.

The whole body folate content increased from 379 to $529 \mu \mathrm{g}$ during the 3 -week period. Some part of this increase was no doubt attributable to the unexpectedly 
high level of ruminal synthesis in the 3 -week-old kids, but the intake of folate with the colostrum and early milk could have been more than enough to account for the increase. If we assume an average milk yield of $2 \cdot 2 \mathrm{~kg} / \mathrm{d}$ during the Ist week of lactation and a folate concentration of $70 \mu \mathrm{g} / \mathrm{kg}$, then the total secretion of folate during this week was $1080 \mu \mathrm{g}$. Since each of the kids was one of twins it would have received about $500 \mu \mathrm{g}$ - rather more than the whole body folate at birth.

The above estimates are only approximate, but the comparatively small average net increase of only $150 \mu \mathrm{g}$ in the whole body folate during the 3 -week period in which their weight had more than doubled, and the sharp fall in liver folate concentration, suggest that folate balance in the kid is precarious until the rumen function is established. Any marginal deficiency in folate would be aggravated by pre-partum milking, whose effect is to deprive the kid of most of the folate that it would normally receive with the colostrum and early milk.

\section{General}

The folate binding in milk exemplifies a type of passive trapping process that is already familiar from the literature on the protein binding of vitamin $B_{12}$ in milk (Gregory, 1954; Gregory \& Holdsworth, 1955) and of steroid hormones in blood (cf. Jensen \& Jacobson, r962; Briggs \& Brotherton, I970). It may be that folate binder occurs in all the body tissues and constitutes the mechanism of folate homoeostasis. Similarly, in the gut, the uptake of folate may be mediated through the agency of folate binder, and the relative avidities of different natural folates for the binder could determine the differences (cf. Butterworth, 1968) in their biological availability. These questions remain to be answered; the possible importance of folate binder in the regulation of folate metabolism and in nutrition will no doubt encourage further research.

\section{REFERENCES}

Becroft, D. M. O. \& Holland, Y. T. (1966). N.Z. med. F. 65, 403.

Briggs, M. H. \& Brotherton J. (1970). Steroid Biochemistry and Pharmacology p. 357.: London Academic Press.

Butterworth, C. E. Jr. (r968). Br. F. Haemat. 14, 339.

Ford, J. E., Salter, D. N. \& Scott, K. J. (1969). F. Dairy Res. 36, 435.

Ford, J. E. \& Scott, K. J. (1969). Int. Congr. Nutr. vir. Prague, r969. Abstr. F-Iz.

Ghitis, J., Mandelbaum-Shavit, F. \& Grossowicz, N. (1969). Am. F. clin. Nutr. 22, I 56.

Ghitis, J. \& 'Tripathy, K. (1970). Am. F. clin. Nutr. 23, 14I.

Gregory, M. E. (I954). Br. F. Nutr. 8, 340.

Gregory, M. E. \& Holdsworth, E. S. (1955). Biochem. F. 59, 329.

Herbert, V. ( $196 \mathrm{r})$. F. clin. Invest. 40, $8 \mathrm{r}$.

Herbert, V. (1962). Trans. Ass. Am. Physns 75, 307.

Hoffbrand, A. V., Newcombe, B. F. A. \& Mollin, D. L. (1966). F. clin. Path. 19, I7.

Jensen, E. V. \& Jacobson, H. I. (1 962). Recent Prog. Horm. Res. 18, 387.

Johns, D. G., Sperti, S. \& Burgen, A. S. V. (196r). F. clin. Invest. 40, I684.

Karlin, R. (1967). Int. Z. VitamForsch. 37, 334.

Metz, J., Zalusky, R. \& Herbert, V. (I968). Am. F. clin. Nutr. 21, 289.

Waters, A. H. \& Mollin, D. L. (196r). F. clin. Path. 14, 335. 